NBER WORKING PAPER SERIES

\title{
MOTHERS' AND FATHERS' LABOR SUPPLY \\ IN FRAGILE FAMILIES: \\ THE ROLE OF CHILD HEALTH
}

\author{
Hope Corman \\ Nancy E. Reichman \\ Kelly Noonan \\ Working Paper 9918 \\ http://www.nber.org/papers/w9918
}

NATIONAL BUREAU OF ECONOMIC RESEARCH

1050 Massachusetts Avenue

Cambridge, MA 02138

August 2003

The views expressed herein are those of the authors and not necessarily those of the National Bureau of Economic Research.

(C2003 by Hope Corman, Nancy E. Reichman, and Kelly Noonan. All rights reserved. Short sections of text, not to exceed two paragraphs, may be quoted without explicit permission provided that full credit, including (C) notice, is given to the source. 
Mothers' and Fathers' Labor Supply in Fragile Families: The Role of Child Health Hope Corman, Nancy E. Reichman, and Kelly Noonan NBER Working Paper No. 9918

August 2003

JEL No. J22, I12

\title{
ABSTRACT
}

We estimate the effect of poor child health on the labor supply of mothers and fathers post welfare reform, using a national sample of mostly unwed parents and their children-a group at high risk of living in poverty. We account for the potential endogeneity of child health and find that having a young child in poor health reduces the mother's probability of working, the mother's hours of work, and the father's hours of work. These results suggest that children's health problems may diminish their parents' capacity to invest in their health.

\author{
Hope Corman \\ Rider University \\ 2083 Lawrenceville Road \\ Lawrenceville, NJ 08648 \\ and NBER \\ corman@rider.edu \\ Nancy E. Reichman \\ National Center for Children in Poverty \\ Mailman School of Public Health \\ Columbia University \\ 215 West $125^{\text {th }}$ Street, $3^{\text {rd }}$ Floor \\ New York, NY 10027-4426 \\ nr2058@columbia.edu \\ Kelly Noonan \\ Rider University \\ 2083 Lawrenceville Road \\ Lawrenceville, NJ 08648 \\ and NBER \\ knoonan@rider.edu
}




\section{Introduction}

A growing body of research indicates that low socioeconomic status in early childhood sets the stage for increasing disadvantages in both health and educational capital over the child's life course and can cause low socioeconomic status to persist for generations. Case, Lubotsky \& Paxson (2002) examined why children from families with low socioeconomic status have poor health and why the health differential between poor and non-poor children gets larger as the children age. They presented a model in which a child's health deteriorates because of a health shock, the negative effects of which can be offset, at least in part, by parental investments in his or her health. Because wealthier parents will invest more in their children's health and because older children have been subjected to more shocks, the difference in child health between poor and non-poor children increases with age. Currie \& Stabile (2002) extended the analysis by investigating whether poor children are less able to recover from each health shock or whether they tend to experience a greater number of shocks. They found that the latter explains the widening socioeconomic gap in child health with age.

These recent studies have focused primarily on causality in one direction, from income to health, but have suggested that feedback from child health to parents' income may play a role in shaping children's health trajectories. Other research, including a recent study of the effects of child health on parents' relationship stability (see Reichman, Corman \& Noonan 2003), indicates that child health does affect family resources and supports the notion that child health and family income interactively and jointly determine children's health and economic trajectories.

We use data from the national Fragile Families and Child Wellbeing Study of mostly unwed parents to estimate the effects of poor child health on two potential sources of financial resources available to the child - the labor supply of the child's mother and that of the child's 
father. The time commitment involved in caring for a child in poor health may inhibit parents' ability to participate in the labor market, resulting in both lower family income and reduced ability to invest in the child's health. Thus, children born in poor health may be at risk for adverse long-term health and economic outcomes both directly (because they have the health condition) and indirectly (through family income). We use a national sample of mostly unwed parents and their children — a group at high risk of living in poverty— to investigate the second issue in the post welfare reform era.

\section{Background}

Having a child in poor health imposes additional time and financial constraints for parents that can impact their labor supply, and ultimately, the financial resources available to the child. The added time constraints would imply reduced labor force participation, whereas additional financial constraints might lead to increased labor force participation. Children's health problems also may increase the cost of child care and reduce its availability, which would likely reduce parents' (particularly mothers') labor force participation. The net effects of these child health-related push and pull factors on the labor supply of mothers have been estimated in a number of studies, but few have analyzed data collected after the implementation of the Personal Responsibility and Work Opportunity Reconciliation Act (PRWORA) legislation of 1996, which

may have dramatically altered the equation by imposing new pressure on mothers of young children to work. Below we review the previous literature of the effects of poor child health on maternal labor supply.

As background for her own study, Powers (2003) provides an excellent review of the early literature on the effects of poor child health on labor supply of the mother, including a 
previous study of hers (Powers 2001) that investigated this issue using the School Enrollment Supplement to the October 1992 Current Population Survey. Most of the 12 studies she reviewed found reduced labor force participation among mothers of disabled children; a few found no effects. Although the studies varied considerably in the way they defined child disability, they used similar sets of control variables, which included maternal sociodemographic characteristics, family structure, and regional economic conditions. Many also included policy variables, such as the generosity of state welfare benefits. The studies tended to focus on single mothers, although a few also addressed the labor supply of married mothers. All used data that predated welfare reform.

Several additional recent studies have contributed to the growing literature on this topic. Norberg (1998) used the 1994 wave of the National Longitudinal Survey of Youth (NLSY) to examine the future behavior of the mother based on information at the birth of the child. She examined the mother's labor force participation going forward each of the five years she studied. In addition, she had specific medical information about the child at the time of the birth: whether the child had been growth retarded in utero, whether the child had been born preterm, whether the child had an extended length of hospitalization after birth, and whether the child had any birth defects. She found that certain high-risk health problems at birth do reduce the mother's labor force participation, and that the effect of poor child health is stronger in years 3,4 , and 5 than in years 1 and 2, controlling for whether the mother had a male partner at baseline and many other maternal characteristics. The unique contributions of the Norberg study are that it: (1) used longitudinal data beginning at the child's birth; (2) included very detailed measures of the child's health; (3) analyzed labor force participation over a five year time span rather than a shorter time interval for which it might be difficult to detect effects; (4) used a sibling fixed-effects model in 
order to control for unobserved factors that might affect both the likelihood of a woman having a child in poor health and of returning to work; and (5) controlled for the mother's cognitive ability (measured by the Air Force Qualifying Test), her work history, and her heath status.

Roberts (1999) used the 1987 National Medical Expenditure Survey to look at the effect of having any family member (not just children) with a mental illness on labor market participation and hours of work for both men and women. She found that having a family member with mental illness did not significantly impact labor market participation for women, but that it had a negative and significant impact on hours worked for both men and women when physical illness was also present. The magnitude of the result was small-a $1 / 2$ hour per week reduction among those who work. A key contribution is that it considered labor force effects for both men as well as women.

Case, Lubotsky \& Paxson (2002) used data from the 1997 Panel Survey of Income Dynamics to examine health trajectories of children by family socioeconomic status. They found that differences in child health between poor and non-poor children increase with age, largely because parental investments in their children's health are inversely related to income. Although their primary focus was on the effects of income on child health, they did suggest that child health could affect income. In testing for causality in this (reverse) direction, they found that a child being low birthweight or having been in a neonatal intensive care unit had no effects on parents' labor force participation or hours of work for each of the first three years of the child's life. The contributions of this study, other than their excellent analysis of the effect of income on child health, are that they: (1) examined labor force participation of fathers as well as mothers, (2) used longitudinal data beginning at the child's birth, and (3) controlled for individuals' work history. 
Earle and Heymann (2002) used a sample of former welfare recipients from the NLSY to investigate the effect of poor child health on job loss. They found that former welfare recipients were $33 \%$ more likely to experience a job loss if they had a child with an activity or schoolrelated limitation. Key contributions of this study are that it: (1) focused on former welfare recipients--a group at high risk for employment instability; (2) controlled for the mother's health when examining the effect of child health; and (3) controlled for local labor market conditions and state welfare generosity.

Porterfield (2002) used 1992 Survey of Income and Program Participation (SIPP) data to examine the effect of having a child age $0-19$ with a disability (defined as having a developmental disorder for children under age six, and having any limitation on activities of daily living for children aged 6-19) on the mother's decision to work part-time, full-time, or not at all. She examined the effects separately for married and unmarried mothers. She found that having a young disabled child is a strong disincentive to working full-time for both married and unmarried mothers, and that it is a disincentive to working part-time (versus not working) among married mothers. The unique contributions of this study are that it controlled for: (1) the age of the disabled child, (2) whether the mother was disabled, and (3) both earnings and disability status of the child's father if the parents were married.

Powers (2003), using the 1991-1992 SIPP, considered the effects of poor child health on mothers' hours worked and changes in hours, using a number of alternative measures of poor child health based on respondents' reports of physical activity limitations, schooling activity limitations, participation in therapy or diagnostic services, receipt of SSI, physical limitations to daily living, and specific diagnoses such as autism, mental retardation, or use of walking aids among their children who were ages $0-21$. She found that child disability reduced participation 
and hours of work for both single and married women. In addition, in models of changes in labor force participation and hours worked, she found that, for married women, the likelihood of participating or of increasing hours were significantly lower when a disabled child was present. The unique contributions of this study are that it: (1) used a number of different detailed measures of child health; (2) looked at changes in hours in addition to hours themselves; (3) included some information about the father-age, education, and health status, and (4) included local labor market conditions and welfare/SSI generosity.

As far as we know, Bednarek \& Hudson (2003) is the only study of the effect of child health on parents' labor supply that used post-welfare-reform data. They used the Medical Expenditure Panel Survey from 1996-1999 to estimate the effects on maternal labor supply (participation, full time/part time/not at all, and hours) of having a child age $0-17$ with physical and cognitive limitations, enrollment in special education or related services, or behavioral and emotional problems (determined from the Columbia Impairment Scale). The unique features of this study are that it: (1) separated the sample into women with a male partner in the household (married or cohabiting) and those without a male present, whereas almost all other studies assumed that unmarried women are single parents; ${ }^{1}$ (2) controlled for fathers' assets, wages, and health insurance if he was present in the household; and (3) controlled for local labor market conditions and state welfare generosity.

The main contribution of the present study is that we estimate effects of child health on father's, as well as mother's, labor supply. We incorporate detailed father variables, such as health status, having served in the military, having received job training, and having ever been convicted of a crime. We also advance the literature on the effects of child health on maternal 
labor supply (and initiate the analysis of paternal labor supply) in several important ways: (1) we include detailed father variables in the mother equation (and vice versa), even when the father and mother are not living together (no previous studies have done this); (2) we consider a range of parental relationships (most previous studies incorporated only marital status; the Porterfield study considered cohabitation; no other studies looked at the range of relationships among unmarried parents that we do); (3) we consider whether the mother and father have with children with other partners, which can complicate the allocation of parents' time and financial resources within families (no previous studies have done this); (4) we account for the potential endogeneity of child health in our models (among the recent studies that we have reviewed, only the Norberg study directly accounted for potential endogeneity, using sibling fixed-effects); (5) we use a longitudinal data set, so that the temporal ordering of events is clear, on a cohort of children all the same age and starting at birth, so that the analysis is not complicated by differential timing of births or different ages of children and the parents have not yet responded to the "shock" of having a child in poor health (of the recent studies, only the Norberg and the Case, Lubotsky \& Paxson studies used such longitudinal birth cohort samples); (6) we analyze data 4-5 years after the 1996 welfare reform legislation, as mothers have faced increasing pressures to work (only the Bednarek \& Hudson study used post-welfare-reform data); and (7) we include the parent's own employment status at the time of the birth (of recent studies, only the Norberg and the Case, Lubotsky \& Paxson studies included work history), measures of both mother's and father's own health in mother's labor supply equations (of the recent studies, only the Powers and the Porterfield studies included both mother's and father's health in the mother's labor supply equation, but only for married women), and local labor market conditions in all models (of recent

\footnotetext{
${ }^{1}$ Empirical studies have found that the wellbeing of women in cohabiting relationships (and their children) falls somewhere between that of their married and single counterparts. See, for example, Lillard, Brien \&Waite (1995),
} 
studies, only the Powers, Earle \& Heymann, and Bednarek \& Hudson studies included such information).

\section{Analytical Framework}

We consider the following model to estimate the effect of poor child health on a parent's labor supply:

(1) Labor supply $=f$ (Own wage rate, wage rate of child's other parent, quality and quantity of children, labor market opportunities, availability of public support, $\mu$ )

A parent's labor supply is a function of his or her earnings capacity (wage), the child's other parent's wage, the quality and quantity of their children (together and with other partners), their labor market opportunities, and the availability of public support. The labor supply function may also contain another set of factors, $\mu$, that are unobserved. To estimate this model, we need good measures or proxies for parents' wages, the quantity and quality of their children, and their local labor market opportunities and policy environments. For wages, we use a set of characteristics including age, race/ethnicity, nativity, education, work history, and health status. We also include measures of the parents' relationship status, which is likely to play a role in decisions about labor market participation. We focus on the labor supply effects of one measure of child quality — child health, but we also consider the child's gender. For quantity of children, we include whether the birth was a multiple, as well as whether the parents have other children together and whether each has step-children. For local labor markets, we include city

Wu (1995), and Manning \& Smock (1997). 
unemployment rates and average wages. Finally, we include state fixed effects to capture availability of public support that may vary by state.

\section{Data}

The Fragile Families and Child Wellbeing Study follows a cohort of new parents and their children in 20 US cities (in 15 states). The study was designed to take a longitudinal look at the conditions and capabilities of new (mostly unwed) parents, the nature of their relationships, factors that push them together and those that pull them apart, and the long-term consequences for parents, children, and society of new welfare regulations, stronger paternity establishment, and stricter child support enforcement. The data, when weighted, are representative of births in US cities with populations over 200,000. Both the mothers and fathers were interviewed in the hospital at the time of the birth (fathers were interviewed by telephone or in-person outside of the hospital when the interview was not completed in the hospital), again when the child was one year old, and very recently, a third time when the child was three years old. A fourth follow-up interview with both parents is planned for when the child is five years old. ${ }^{2}$ Baseline interviews were conducted with 4898 mothers from 1998 to $2000 ; 89 \%$ of the mothers who completed baseline interviews were re-interviewed when their children were between 12 and 18 months old.

The Fragile Families data are well suited for analyzing the effects of child health on labor force participation because they were collected as part of a longitudinal birth cohort study and include: (1) considerable detail about labor force activity, (2) characteristics (e.g., health status) of fathers as well as mothers, and (3) detailed information on the parents' relationship status,

\footnotetext{
${ }^{2}$ Additional background on the research design of the Fragile Families and Child Wellbeing Study is available in Reichman et al. (2001).
} 
living arrangements, and other children (together and with other partners). In terms of parental relationships, each wave of the survey asks parents whether they are married to each other, cohabiting, romantically involved but not cohabiting, friends, or have little or no contact—and when applicable, if they have another partner.

\section{Descriptive Analysis}

The purpose of this paper is to estimate the effects of poor child health on parents' labor supply. Below we describe the measures we use in our analyses, present summary statistics (in Table 1), and point out many salient characteristics of the sample.

We estimate two labor supply outcomes for both the mother and the father: (1) whether or not (s)he was working at the time of the follow-up interview, and (2) the number of hours that (s)he worked the week prior to follow-up. Table 1 shows that over half (54\%) of the mothers were working. The average number of hours per week for all mothers (both working and nonworking) was 19.6; the corresponding figure for mothers who were working was 36 hours per week (not shown in table). As we would expect, a greater proportion of the fathers (over three quarters) than the mothers were working at the time of the follow-up interview; ${ }^{3}$ the average number of hours worked per week for all fathers was $36 .{ }^{4}$

We also present the characteristics of the children, mothers, and fathers, as well as other measures that we include in our models. As discussed earlier, we consider several measures of both child quality and quantity. We consider a child to have poor health if at least one of the following criteria is met (all are from mothers' reports): the child weighed less than 4 pounds at

\footnotetext{
${ }^{3}$ Four percent of fathers were incarcerated at the time of the follow-up interview (not shown in table).

${ }^{4}$ The average number of hours per week for fathers, conditional on employment, was 45 (result not shown in table).
} 
birth (3\%), ${ }^{5}$ the mother reported at follow-up that the child had a disability $(2.4 \%)$, or the child was neither walking nor crawling (1.4\%) by the time of the follow-up interview 12 to 18 months after the birth (figures not shown in table). We used a stringent definition of low birthweight rather than the typical 5.5-pound cutoff in order to better identify cases of serious and chronic health problems (many of the heavier low birthweight children do not experience long-term health problems). Our goal is to identify children with a serious health shock from birth. Six percent of the children in our sample meet the criterion for having poor child health. ${ }^{6}$

We also include the gender of the focal child, whether the birth was a multiple, whether the parents had any other children together, and whether each parent had at least one child with another partner. Approximately one third of the parents had other children; about the same proportion of both fathers and mothers had at least one child with another partner.

We go beyond whether the father was present in the mother's household to characterize the parents' relationship; we consider whether the parents were married, cohabiting, romantically involved or friends, or rarely or never talked. About three quarters of the new parents were not married at baseline; about half of those lived together.

In general, we use mother reports for information about the mother and father reports for information about the father. However, in cases where father's data are missing, we use mother reports about the father if these are available. Both educational attainment and Medicaid (whether the birth was covered by Medicaid) are included as proxies for poverty status. With over half of the births covered by Medicaid, it is clear that a large proportion of the sample is poor or near-poor.

\footnotetext{
${ }^{5}$ In a separate analysis, we compared mother respondents' reports of birthweight with the corresponding figures from the hospital records for a sub-sample of over 1800 cases. We found exact matches (to the ounce) between the maternal reports in the survey and the entries in the hospital charts in $76 \%$ of the cases, and matches within 8 ounces in $94 \%$ of the cases. The correlation of babies' birthweight from the two sources was .98 .
} 
We take advantage of the longitudinal nature of our data by estimating models that control for labor supply at baseline. We control for mother's baseline labor supply by including a measure of whether or not the mother had worked at all in the two years prior to the birth of the child. For the father's baseline labor supply, we include whether the father was employed at the time the baby was born.

We have excellent information on the father even when he was not present in the household. In addition to his education and race, we have information on whether or not the father had ever been convicted of a crime (37\%), had received any vocational training (25\%), and had served in the military (10\%). We would expect all of these measures to affect the father's labor market opportunities. We also include information on his (as well as the mother's) health status; well over half of both fathers and mothers reported at baseline that they were in very good or excellent health.

Finally, we include city unemployment rates and wages to characterize local labor markets; adoption and neonatal intensive care availability as identifiers for poor child health (this will be discussed later in the sampling strategy section); and the mother's baseline state of residence to capture state policies and environments that may impact parents' family formation behaviors and labor market participation.

\section{Modeling Strategy}

As discussed earlier, having a child in poor health increases the parents' financial and time constraints and, as a result, their labor supply may either increase or decrease. To estimate the effect of poor child health, we estimate Equation (1), operationalized as follows:

\footnotetext{
${ }^{6}$ The percentages for the individual measures sum to more than 6 because some children fit more than one criterion.
} 
(2) Parent's labor supply $=f$ (child health, other measures of child quality, child quantity, mother and father characteristics, city labor market characteristics, state policy and economic environments, $\mu$ )

Estimation of Equation (2) would be straightforward if the measured child health were truly random (exogenous). It is possible, however, that despite our best efforts at measuring true health shocks, we may capture non-random components of child health that are correlated with unobserved determinants of the parent's labor supply $(\mu)$ that even the state fixed effects do not eliminate. If so, our measure of child health would be endogenous and its estimated effect on parent's labor supply would be biased.

Since we may not be completely successful at characterizing poor child health as a random event, we need to consider causes of possible endogeneity. We can imagine scenarios in which the unobserved determinants of child health and labor supply would be positively correlated, and others in which the correlation would be negative. For example, a mother with a strong preference for earnings and labor market participation may experience a high level of prenatal stress (which we cannot measure) that may have adverse consequences on her infant's health; under this scenario, there would be a positive correlation between poor child health and the mother's labor market participation. On the other hand, a parent with a high rate of time preference may be less likely than other parents to invest in both the health of the unborn child and in a career, resulting in a negative correlation between poor child health and labor supply. Because we cannot be certain that child health is exogenous, we model our system with two equations, one of which expresses child health as a function of parental characteristics and health care inputs, as follows: 
(3) Child Health $=g$ (mother \& father characteristics, prenatal \& perinatal health inputs)

\section{Labor supply models}

As described earlier, we use two different measures of the parent's labor supply: a dichotomous measure of whether or not the parent was employed at the time of the follow-up interview and a censored measure of the number of the hours the parent worked the previous week (many parents, especially mothers, had zero hours).

\section{Parent's labor force participation}

We let $\mathrm{CW}_{\mathrm{i}}^{*}$ represent the underlying employment status for individual $i$, conditional on the health of the child and other characteristics. In particular, assume that $C W_{i}^{*}$ is a function of poor child health $\left(\mathrm{CH}_{i}\right)$ and mother and father characteristics, such that:

$$
C W_{i}^{*}=\beta_{C H} C H_{i}+\beta^{\prime} X_{i}+\varepsilon_{i}
$$

where $X_{i}$ is a vector of observed characteristics and $\varepsilon_{i}$ is the unobserved variation. Since $C W_{i}^{*}$ is a latent variable, it is not directly observed. The observed outcome, $C W_{i}$, for individual $i$ is defined by the sign of the latent variable as follows:

$$
C W_{i}= \begin{cases}1 & \text { if } C W_{i}^{*} \geq 0 \\ 0 & \text { otherwise }\end{cases}
$$

\section{Parent's hours of work}

We let $\mathrm{H}_{\mathrm{i}}{ }^{*}$ represent the number of hours of work for the individual $i$ conditional on the health status of the child and other demographic and economic characteristics. In particular, assume that that $H_{i}{ }^{*}$ is a function of poor child health, $\mathrm{CH}_{i}$, characteristics of the mother, characteristics of the father, and other unobserved characteristics such that: 


$$
\mathrm{H}_{\mathrm{i}}^{*}=\gamma_{C H} C H_{i}+\gamma_{X}^{\prime} X_{i}+v_{i}
$$

where $X_{i}$ is a vector of observed characteristics and $v_{i}$ is the unobserved variation. Since $H_{i}^{*}$ is a latent variable, it is not directly observed. The observed outcome, $H_{i}$, for individual $i$ is defined as follows:

$$
H_{i}= \begin{cases}0 & \text { if } H_{i}^{*} \leq 0 \\ H_{i}^{*} & \text { otherwise }\end{cases}
$$

\section{Child health model (Equation 3)}

We assume that the probability that a child has poor health, $\mathrm{CH}_{i}{ }^{*}$, is a linear function of parent characteristics and prenatal and perinatal health care availability:

$$
C H_{i}^{*}=\beta_{Z} Z_{i}+u_{i}
$$

where $Z_{i}$ is a vector of observed characteristics and $u_{i}$ is the error term for individual $i$. The data for $Z_{i}$ will be taken primarily from the baseline survey.

Since $\mathrm{CH}_{i}{ }^{*}$ is a latent variable, it is not directly observed. The observed health, $\mathrm{CH}_{i}$, for individual $i$ is defined by the sign of the latent variable as follows:

$$
C H_{i}= \begin{cases}1 & \text { if } C H_{i}^{*} \geq 0 \\ 0 & \text { otherwise }\end{cases}
$$




\section{Joint estimation of labor force participation and child health}

To account for the possibility that child health is endogenous, we use a full-information maximum likelihood (FIML) estimator that is based on both the labor force participation equation and the poor child health equation. We assume that the error terms in both equations are normally distributed and allow for the possibility that they are correlated. This estimation allows us to test whether child health is endogenous (if it is, then the correlation between the error terms, $\rho$, will be significant).

For the labor force participation equations, we use a bivariate probit specification because the outcome measures are dichotomous. If certain conditions are met (described later) and $\rho$ is not significantly different from zero, it follows that child health is exogenous and that a standard probit is the more appropriate model. We identify this two-equation system by imposing exclusion restrictions, described in the following section. ${ }^{7}$

\section{Joint estimation of hours worked and child health}

The number of hours worked is a censored variable, and under the assumption of normality it can be estimated using a Tobit model. To account for the potential endogeneity of child health, we use Limited Information Maximum Likelihood (LIML) to estimate a two-step probit model. In the first step, we estimate poor child health and calculate predicted values. We then use the predicted values of poor child health in the second step to estimate hours of work using a Tobit model, and adjust the standard errors per Murphy \& Toppel (1985). Such a twostep procedure is necessary in order to obtain unbiased estimates of the effects of poor child health on hours of work if child health is endogenous. 


\section{Identifiers}

We include proxy measures for prenatal and perinatal care in Equation (3), both because they are predictors of child health and also to identify the systems of equations we use to test for (and potentially to control for) the endogeneity of child health. We use two such identifiers: the number of adoption agencies (public or private) per 10,000 women in the city in which the child was born and the presence (or lack thereof) of a Level III neonatal intensive care unit in the hospital where the baby was delivered. ${ }^{8}$ The first may be related to the wantedness of the child (see, for example, Grossman \& Joyce 1990, which showed that children who are more wanted tend to receive greater levels of prenatal care). In the father labor supply models, we use the mother's health status as an additional identifier.

For the identifiers to be valid, they must satisfy two conditions. Condition \#1: They must be significant predictors of poor child health. Condition \#2: They must be uncorrelated with the labor supply outcome.

\section{Results}

In Tables 2 and 3, we present multivariate results for mothers and fathers, respectively, for our two outcomes - labor force participation and hours of work. For each model, we exclude cases for which we do not have full information at both waves. Standard errors are corrected for city clustering of observations using the Huber-White method.

\section{Mother's labor supply}

\footnotetext{
${ }^{7}$ When valid identifiers are not available, an alternative is to set restrictions on $\rho$ (see Altonji, Elder \& Taber 2000).

${ }^{8}$ Data on adoption agencies were obtained from the National Adoption Information Clearinghouse (NAIC) at (http://www.calib.com/naic/database/nadd/naddsearch.cfm) for current data as of March 2003; population data were obtained from the 2000 US Census; and data on Level III NICUs were collected by the authors.
} 
Table 2 shows effects of child and other characteristics on the mother's labor supply. The second column shows probit coefficients for whether the mother was working at the time of the follow-up interview. ${ }^{9}$ Because the coefficients in these models are not easy to interpret, we also present marginal effects in the third column. As discussed in the previous section, we also estimated this model using a bivariate probit specification to allow us to test for the endogeneity of child health. Those results, presented in Appendix A, indicate that child health is not endogenous in the mother's labor force participation equation, as shown by the non-significance of $\rho .^{10}$

We find that having a child in poor health decreases the likelihood that a mother will work by between 4 and 16 percentage points. ${ }^{11}$ This estimate is in the range of that found by others (Powers 2003 and several studies reviewed in that article; Porterfield 2002; Norberg 1998).

Several other measures of child quality and/or quantity also significantly affect whether mothers participate in the labor force. As explained earlier, we distinguish between the existence of full biological siblings, mother's children with other partners, and father's children with other partners. If the mother and father have other children together, the probability that the mother works is decreased by 3 percentage points, and if she has at least one child with another partner, the probability is reduced by 2 percentage points. The father having any children with other partners significantly increases the mothers' labor force participation by three percentage

\footnotetext{
${ }^{9}$ We ran additional probit models for whether the mother had worked at all since the birth of the child. Results from this alternative definition of maternal labor market participation were very similar to those shown here for "current" labor market participation. Results from these auxiliary models are available from the authors upon request.

${ }^{10}$ The tests we used for the validity of the identifiers in the bivariate probit analyses are described in detail in Reichman, Corman \& Noonan (2003). In the present analysis, we performed the same set of tests and found that adoption agencies and level III NICUs are valid identifiers for the labor force participation equation for mothers.

${ }^{11}$ The marginal effect is 10 percentage points, with a $95 \%$ confidence interval of $4-16$ percentage points.
} 
points. ${ }^{12}$ Finally, controlling for child health and all of the other covariates, neither the gender of the child nor whether the birth was a multiple are significant predictors of the mother's labor force participation.

The relationship status of the parents at the time of the child's birth is significantly associated with the mother's labor force participation one year later. Whether they and the child's father cohabited, were romantically involved or friends, or had no relationship at baseline, unmarried mothers are about 7 percentage points more likely to work than women who were married. ${ }^{13}$ Thus, it appears that marital status may be a more relevant distinction than coresidence (i.e., being married or cohabiting) in determining maternal labor force participation.

Generally, mother's characteristics affect her labor force participation in the expected directions; for example, mothers who worked in the two years prior to the birth of this child were significantly more likely to work following the birth (it increases the likelihood by almost 40 percentage points).

We included father's characteristics even when the mother was neither married nor cohabiting with him because (1) over ninety percent of the unmarried parents in the sample of 3998 births were in some type of relationship with one another at the time of the birth, and (2) relationships among unmarried parents tend to be quite fluid (Graefe \& Lichter 1999), with some new parents entering cohabiting unions or forming more serious relationships after the birth of their child (Carlson, McLanahan \& England 2003). After controlling for the mother's own characteristics, child characteristics, and the parents' relationship status, we find that father's

\footnotetext{
${ }^{12}$ Wald tests indicate that the effect of the mother having at least one other child with the father is equivalent to that of the mother having at least one child with another partner; the effect of the father having at least one child with another partner, however, is significantly different than the effect of the parents having at least one other child together (results not shown).

${ }^{13}$ For the last group (those who had no relationship with the father), the effect is not statistically significant.
} 
individual characteristics, as a group, significantly impact mother's labor force participation at the $1 \%$ level (result not shown).

As expected, mother's labor force participation is positively related to both the average wage rate for females of childbearing age and the unemployment rate in her city. High wages are an incentive to participate in the labor market and also may be correlated with cost of living, which may increase labor market participation. The positive association we find between labor force participation and city unemployment rate may reflect an "added worker effect," in that mothers may be working to compensate for earnings of family members who are unemployed or in jeopardy of losing their jobs.

In the last two columns of Table 2, we present Tobit results for the number of hours the mother works per week, as well as marginal effects that represent the average change in hours for the $54 \%$ of mothers who are working. A shortcoming of the LIML estimator is that it does not estimate the value or significance of the correlation between the error terms in the system of equations (in this case, the error terms in the child health and the mother's hours of work equations). Our estimates for labor force participation suggest that child health is not endogenous to hours worked, but to further test this assumption we estimate a simultaneous equation model that treats hours worked as a censored variable and child health as continuous (results not shown). This estimation indicates that the correlation between the error terms is not significant, providing further evidence of the validity of the single equation results presented in Table $2 .{ }^{14}$

Having a young child in poor health significantly reduces the number of hours that employed women work - by approximately four per week; this result is consistent with that found by Bednarek \& Hudson (2003). Having other children with the same father reduces the

\footnotetext{
${ }^{14} \mathrm{We}$ tested and found that the two instruments we used in the labor force participation model are also valid for estimating the effect of poor child health on mother's hours of work.
} 
mother's weekly hours of work by .8 and having at least one child with another partner reduces her weekly hours by .1. The father having children with another partner has the opposite effectit increases the mother's hours of work by 1.7 per week. It appears that mothers are working a greater number of hours to compensate for resources being diverted to their partners' other children.

Mothers who were not married to their children's fathers at baseline work approximately two to three more hours per week than mothers who were married, holding all else constant. Again, the effects of mother and father characteristics are generally as expected and father's characteristics, as a group, are significant predictors of mother's hours of work (latter result not shown).

\section{Father's labor supply}

Table 3 presents labor supply results for fathers. In the first two columns we present probit estimates and marginal effects for whether the father was employed, and in the second two columns we show Tobit coefficients and marginal effects for the number of hours the father worked per week. Again, we tested and found that child health is not endogenous to the father's labor force participation (bivariate probit results shown in Appendix A) or number of hours of work. ${ }^{15}$ Hours of work were not available for the $23 \%$ of fathers who did not complete the follow-up interview. Results from a Heckman sample selection model using data on all fathers (results not shown) indicate that sample selection does not appear to be a significant problem. ${ }^{16}$

\footnotetext{
${ }^{15}$ The tests for the endogeneity of child health for father's hours of work are identical to those we used for mother's hours. Note again that a third identifier, mother's health status, was also included in both father estimations.

${ }^{16}$ This is not surprising, given findings by Teitler, Reichman \& Sprachman (2003) that fathers in the sample who did not complete interviews at baseline were similar on many observed measures to those who did complete baseline interviews. In addition, characteristics of our full and restricted samples are virtually identical (not shown).
} 
We find that having a child in poor health does not significantly affect whether the father works, but it does reduce employed fathers'work effort by four hours per week. Interestingly, this effect on fathers' hours is very similar to the effect we found on mothers' hours. ${ }^{17}$ The "effects" of additional children depend on whether they are the father's own children and whether they are with another mother. ${ }^{18}$ The father's hours of work are not significantly affected by whether the parents have at least one other child together. The existence of step-children, however, has negative effects on the father's labor supply: When the mother has at least one child with another partner, employed fathers works two fewer hours per week. When the father has least one child with another partner, the likelihood that he will work is reduced by five percentage points, and if he is employed, he will work two fewer hours per week; a possible explanation is that child support enforcement acts as a disincentive to work, creating high marginal "tax" rates. Another is that the father's time commitments to other children leave him less time to work.

Mother and father characteristics generally affect father's labor force participation and hours of work as expected. An interesting finding is that the father having been convicted of a crime significantly reduces the likelihood that he is working by about six percentage points and reduces his weekly hours by 7 if he is employed. Having good or excellent health increases employed father's hours by about two per week. Having been unmarried to the mother at baseline is negatively related to the father's labor force participation a year later, although none of the categories of non-marital relationship status is statistically significant.

\footnotetext{
${ }^{17}$ The effects on parents' hours are largely additive; a supplemental model of parents' combined hours (not shown) indicates that having a child in poor health decreases total hours (the mother's plus the father's hours) by seven per week.

${ }^{18}$ It is important to note that the existence of other children may be endogenous. For example, women with a greater taste for working may have fewer children (see, for example, Nakamura \& Nakamura 1994).
} 
Finally, using the same covariates and model structure, we find that the effects of poor child health on parents' labor supply are stronger for unmarried parents than for married parents (results for unmarried parents presented in Appendix B). ${ }^{19}$ In particular, having a child in poor health reduces the probability that an unmarried mother is working by 13 percentage points (vs. the 10 percentage points for the full sample, controlling for relationship status) and reduces employed mothers' hours of work by 5.6 per week (vs. 4 for the full sample). These results are consistent with those from other studies (Powers 2003 and at least one study reviewed in that article; Powers 2001; Bednarek \& Hudson 2002). The relationship status measures are insignificant in the models for unmarried mothers, which is consistent with findings by Bednarek and Hudson and with our own finding that marital status appears to be more relevant than living together (marriage or cohabitation) in determining mothers' labor market participation and hours of work. For unmarried fathers, there is still no effect of poor child health on labor force participation, but hours of work decrease by 6 per week among those who are employed (vs. 4 for the sample of married and unmarried fathers, combined).

\section{Conclusion}

We found that having a child in poor health reduces the mother's probability of working, the mother's hours of work, and the father's hours of work - particularly so for unmarried parents. Although this may perhaps mean that the children in poor health are getting increased parental resources in terms of time, it may also mean that their parents' capacity to invest financially in their health is diminished, placing them at increased risk for adverse health and economic outcomes in the future.

\footnotetext{
${ }^{19}$ We found no significant results of poor child health on labor supply or hours of mothers or fathers who were married (results not shown).
} 
A major contribution of our study is that we have provided estimates of the effects of poor child health on the labor supply of fathers as well as mothers; we did so using a national longitudinal data set that oversampled unmarried parents in the post welfare reform era. Interestingly, having a child in poor health has the same effect on hours worked for fathers as it does for mothers (a reduction of four hours per week, given that the parent is employed) and the results we found for mothers are similar to those from studies that used different controls and methodologies and almost exclusively used pre- welfare reform data.

An important finding is that the presence of other children and step-children have unique associations with mothers' and fathers' labor supply, even after controlling for the focal child's health status and numerous other covariates. For mothers, having other children with the same father is associated with a reduction in participation (having childen with other fathers has no significant effect). But, when the father has children with another partner, mothers are more likely to work and, for those who do work, hours increase by almost two per week. For fathers, having other children with the mother does not significantly affect hours worked, but having children with other mothers is associated with reductions in both hours worked and the probability that they are employed. Additionally, having step-children also appears to serve as a work disincentive for the father. These results highlight the complexities underlying the economic and health trajectories of children in fragile families. 


\section{References}

Altonji, J. G., T. E. Elder and C. R. Taber (2000). "Selection on Observed and Unobserved Variables: Assessing the Effectiveness of Catholic Schools." NBER. Working Paper: 7831

Bednarek, H. L. and J. L. Hudson (2003). "Child Disability and Mothers' Labor Supply." St. Louis University. Presented at the AEA Meeting, St. Louis

Carlson, M., S. S. McLanahan and P. England (2003). "Union Formation and Dissolution in Fragile Families." Center for Research on Child Wellbeing Working Paper \#01-06-FF

Case, A., D. Lubotsky and C. Paxson (2002). "Economic Status and Health in Childhood: The Origins of the Gradient." American Economic Review 92(5): 1308-1334.

Currie, J. and M. Stabile (2002). "Socioeconomic Status and Health: Why is the relationship stronger for older children?" NBER. Working Paper: 9098

Earle, A. and S. J. Heymann (2002). "What Causes Job Loss Among Former Welfare Recipients: The Role of Family Health Problems." JAMWA 57(1): 5-10.

Folk, K. F. (1995). Single Mothers in Various Living Arrangements: Differences in Economic and Time Resources. School of Family Resources and Consumer Sciences. Madison, University of Wisconsin: 22.

Graefe, D. R. and D. Lichter (1999). "Life Course Transitions of American Children: Parental cohabitation, marriage, and single motherhood." Demography 36(2): 205-217.

Grossman, M. and T. Joyce (1990). "Unobservables, Pregnancy Resolutions, and Birthweight Production Functions in New York City." Journal of Political Economy 98: 983-1007.

Lillard, L. A., M. J. Brien and L. J. Waite (1995). "Premarital Cohabitation and Subsequent Marital Dissolution: A Matter of Self-Selection?" Demography 32(3): 437-57.

Manning, W. D. and P. J. Smock (1997). "Children's Living Arrangements in Unmarried-Mother Families." Journal of Family Issues 18(5): 526-544.

Murphy, K. and R. Topel (1985). "Estimation and Inference in Two Step Econometric Models." Journal of Business \& Economic Statistics 3: 370-379.

Nakamura, A. and M. Nakamura (1994). "Predicting Female Labor Supply: Effects of Children and Recent Work Experience." The Journal of Human Resources 29(2): 304-327.

Norberg, K. (1998). "The Effects of Daycare Reconsidered." NBER. Working Paper: 6769 
Porterfield, S. L. (2002). "Work Choices of Mothers in Families with Children with Disabilities." Journal of Marriage and Family 64: 972-981.

Powers, E. T. (2001). "New Estimates of the Impact of Child Disability on Maternal Employment." American Economic Review Papers and Proceedings 91(2): 135-139.

------ (2003). "Children's Health and Maternal Work Activity: Static and Dynamic Estimates under Alternative Disability Definitions." Journal of Human Resources 38(3).

Reichman, N. E., H. Corman and K. Noonan (2003). "Effects of Child Health on Parents' Relationship Status." NBER. Working Paper \#9610

Reichman, N. E., J. O. Teitler, I. Garfinkel and S. S. McLanahan (2001). "Fragile Families: Sample and Design." Children and Youth Services Review 23(4/5): 303-326.

Roberts, A. A. (1999). "The Labor Market Consequences of Family Illness." The Journal of Mental Health Policy and Economics 2: 183-195.

Teitler, J. O., N. E. Reichman and S. Sprachman (2003). "Costs and Benefits of Improving Response Rates for a Hard-to-Reach Population." Public Opinion Quarterly 67(1): 126138.

Wu, Z. (1995). "The Stability of Cohabitation Relationships: The Role of Children." Journal of Marriage \& Family 57(1): 231-237. 


\section{Outcomes}

Mother Currently Working $(n=3998) \quad .54$

Father Currently Working $(\mathrm{n}=3820) \quad .78$

Number of Hours Mother Works Per Week ( $n=3950)$

Number of Hours Father Works Per Week $(n=3097)$

\section{Child}

Child is in Poor Health $\quad .06$

Male Child $\quad .53$

Multiple Birth $\quad .02$

Parents Have Other Child(ren) Together $\quad .36$

Mother Has Child(ren) With Other Father(s) $\quad .34$

Father Has Child(ren) With Other Mother(s) $\quad .34$

Parents' Relationship (at time of birth)

\# Months Mother Knew Father $\quad 59$

Married at Baseline* $\quad .26$

$\begin{array}{ll}\text { Cohabiting } & .38\end{array}$

Romantic or Friends $\quad .31$

Rarely/Never Talk $\quad .05$

\section{Mother}

Age in years $\quad 25.1$

(standard deviation)

Less than High School ${ }^{*} \quad 34$

High School Grad $\quad .30$

Some College $\quad .25$

College Grad $\quad .11$

Medicaid $\quad .61$

White Non-Hispanic* $\quad .23$

Hispanic $\quad .27$

Non-White/ Non-Hispanic $\quad .51$

Immigrant $\quad .16$

Lived with Both Parents at Age 15

Worked Within 2 years Before Birth $\quad .81$

Health is Very Good or Excellent $\quad .67$

Attends Religious Services Several Times/Month $\quad .39$ 
Table 1: Sample Characteristics (continued)

Proportions

(unless indicated otherwise)

\section{Father}

Age in years

27.7

(standard deviation)

Less than High School*

High School Grad

Some College

.22

College Grad

.11

Attended Vocational School

.25

Served in the Military

.10

Ever Convicted of a Crime $\quad .37$

White Non-Hispanic* ${ }^{*} \quad .20$

Hispanic $\quad .27$

Non-White/ Non-Hispanic $\quad .53$

Immigrant $\quad .15$

Lived with Both Parents at Age $15 \quad .39$

Employed at Time of Birth $\quad .78$

Employment at Time of Birth Missing $\quad .03$

Health is Very Good or Excellent $\quad .60$

Health Status Missing $\quad .16$

\section{Area and Hospital Characteristics ${ }^{\dagger}$}

City Unemployment Rate

Average Full-Time Female Earnings in City (dollars)

Average Full-Time Male Earnings in City (dollars)

\# Adoption Agencies per 10,000 Women Aged 15-44 in

City

Level III NICU in Birth Hospital

${ }^{*}$ Excluded Category in Regression Models

† Data on unemployment rates, earnings and population were obtained from the 2000 U.S.

Census at the following link:

http://factfinder.census.gov/servlet/DTGeoSearchByListServlet?ds_name

=DEC_2000_SF1_U\&_lang=en\&_ts=73400311652

Data on Level III NICUs were collected by the authors.

Data on adoption providers were obtained from the National Adoption Information Clearinghouse (NAIC) at the following link:

http://www.calib.com/naic/database/nadd/naddsearch.cfm 
Table 2: Effects of Child, Mother, Father, Relationship, and Area Characteristics on Mother's Labor Supply

\begin{tabular}{cccc}
\multicolumn{2}{c}{ Mother Currently Working } & \multicolumn{2}{c}{ Mother's Hours of Work } \\
\hline \multicolumn{2}{c}{ Probit } & \multicolumn{2}{c}{ Tobit } \\
\hline $\begin{array}{c}\text { Coefficient } \\
\text { (standard error) }\end{array}$ & Marginal & Coefficient & Marginal \\
& Effect & (standard error) & Effect
\end{tabular}

\section{Child}

Child is in Poor Health

$-.26^{* * *}$

(.08)

$-.10$

$-6.71^{* * *}$

Male Child

.03

(.05)

.01

$(1.87)$

$-4.13$

Multiple Birth

$-.22$

(.19)

$-.09$

.61

(1.20)

.37

Parents Have Other Child(ren) Together

$-.07^{*}$

(.04)

$-.03$

$-4.72$

(4.78)

$-2.90$

$-1.32$

(.92)

$-.81$

Mother Has Child(ren) With Other Father(s)

$-.04$

(.07)

$-.02$

$-.21$

(1.60)

$-.13$

Father Has Child(ren) with Other Mother(s)

$.09^{*}$
$(.05)$

.03

$2.83^{* *}$

(1.27)

1.74

\section{Parents' Relationship}

\# Months Mother Knew Father

.00

$(.00)$

$.19^{* * *}$

(.06)

$.18^{* *}$

(.09)

.20

(.15)

.08

.07

.07

$(1.88)$

.00

(.01)

.00

Rarely/Never Talk

\section{Mother}

Age

Age squared

$.12^{* * *}$

(.02)

$-.00^{* * *}$

(.00)

$.31^{* * *}$

(.04)

$4.74^{* * *}$

2.92

1.85

4.59

(3.40)

2.83

$2.80^{\text {*** }}$

(.66)

1.73

$-.00$

$-.05^{\star \star \star}$

$-.03$

High-School Grad 
Table 2 (cont'd): Effects of Child, Mother, Father, Relationship, and Area Characteristics on Mother's Labor Supply

\begin{tabular}{cccc}
\multicolumn{2}{c}{ Mother Currently Working } & \multicolumn{2}{c}{ Mother's Hours of Work } \\
\hline \multicolumn{2}{c}{ Probit } & \multicolumn{2}{c}{ Tobit } \\
\hline Coefficient & Marginal & Coefficient & Marginal \\
(standard error) & Effect & (standard error) & Effect
\end{tabular}

\section{Mother (continued)}

Some College

$61^{* * *}$

$(.07)$

.23

$15.88^{* * *}$

$.72^{* * *}$

College Grad

(.12)

.26

(2.01)

9.78

Medicaid

$-.31^{* * *}$

(.05)

$-.12$

$19.29^{* * *}$

(2.82)

11.88

Hispanic

$.17^{*}$

(.09)

.07

$-6.81^{\text {*** }}$

(1.18)

$-4.20$

$4.47^{* *}$

(2.24)

2.75

Non-White/ Non-Hispanic

$-.02$

(.11)

$-.01$

.14

(2.60)

.09

Immigrant

$-.11$

(.08)

$-.04$

$-2.57$

(2.29)

$-1.59$

Lived with Both Parents at Age 15

$-.02$

(.04)

$-.01$

$-.40$

(1.03)

$-.24$

Worked Within 2 Years Before Birth

$1.03^{* * *}$

(.04)

.39

$29.43^{* * *}$

(1.94)

18.13

Health is Very Good or Excellent

.00

(.05)

.00

$-.38$

(1.22)

$-.23$

Attends Religious Services Several

Times/Month

$-.03$

(.04)

$-.01$

$-1.63^{*}$

$(.91)$

$-1.00$

Father

Age

$-.03^{* *}$

(.02)

$-.01$

$-.97^{* *}$

(.40)

$-.60$

Age squared

.00

(.00)

.00

$.01^{* *}$

(.01)

.01

High-School Grad

$-.01$

(.03)

$-.01$

$-.36$

(.89)

$-.22$

Some College

.05

(.05)

.02

1.44

(1.10)

.89

College Grad

$-.12$

(.11)

$-.05$

$-3.99$

(2.45)

$-2.46$

Hispanic

$-.01$

(.09)

$-.00$

1.39

(2.21)

.85 
Table 2 (cont'd): Effects of Child, Mother, Father, Relationship, and Area Characteristics on Mother's Labor Supply

\begin{tabular}{|c|c|c|c|c|}
\hline & \multicolumn{2}{|c|}{$\begin{array}{c}\text { Mother Currently Working } \\
\text { Probit } \\
\end{array}$} & \multicolumn{2}{|c|}{$\begin{array}{c}\text { Mother's Hours of Work } \\
\text { Tobit }\end{array}$} \\
\hline & $\begin{array}{c}\text { Coefficient } \\
\text { (standard error) }\end{array}$ & $\begin{array}{l}\text { Marginal } \\
\text { Effect }\end{array}$ & $\begin{array}{c}\text { Coefficient } \\
\text { (standard error) }\end{array}$ & $\begin{array}{l}\text { Marginal } \\
\text { Effect }\end{array}$ \\
\hline \multicolumn{5}{|l|}{ Father (continued) } \\
\hline Non-White/ Non-Hispanic & $\begin{array}{l}.20^{* *} \\
(.09)\end{array}$ & .08 & $\begin{array}{c}7.57^{* * *} \\
(2.32)\end{array}$ & 4.66 \\
\hline Health is Very Good or Excellent & $\begin{array}{l}-.02 \\
(.08)\end{array}$ & -.01 & $\begin{array}{c}-.50 \\
(1.77)\end{array}$ & -.31 \\
\hline Health Status Missing & $\begin{array}{l}.10 \\
(.09)\end{array}$ & .04 & $\begin{array}{c}2.53 \\
(1.97)\end{array}$ & 1.56 \\
\hline \multicolumn{5}{|l|}{ Area Characteristics } \\
\hline City Unemployment Rate & $\begin{array}{l}.09^{* *} \\
(.03)\end{array}$ & .04 & $\begin{array}{c}2.25^{* *} \\
(.82)\end{array}$ & 1.38 \\
\hline $\begin{array}{l}\text { Average Full-Time Female Earnings in } \\
\text { City }\end{array}$ & $\begin{array}{l}.08^{* * *} \\
(.02)\end{array}$ & .03 & $\begin{array}{c}1.97^{* * *} \\
(.46)\end{array}$ & 1.21 \\
\hline Number of Observations & 3998 & & 3950 & \\
\hline Log Likelihood & $-2,358.93$ & & $-11,602.11$ & \\
\hline
\end{tabular}

* Significant at $10 \%$ level; ** Significant at $5 \%$ level; *** Significant at $1 \%$ level Notes: (City) clustered robust standard errors in parentheses; all models include state fixed effects (results not presented). 
Table 3: Effects of Child, Mother, Father, Relationship, and Area Characteristics on Father's Labor Supply

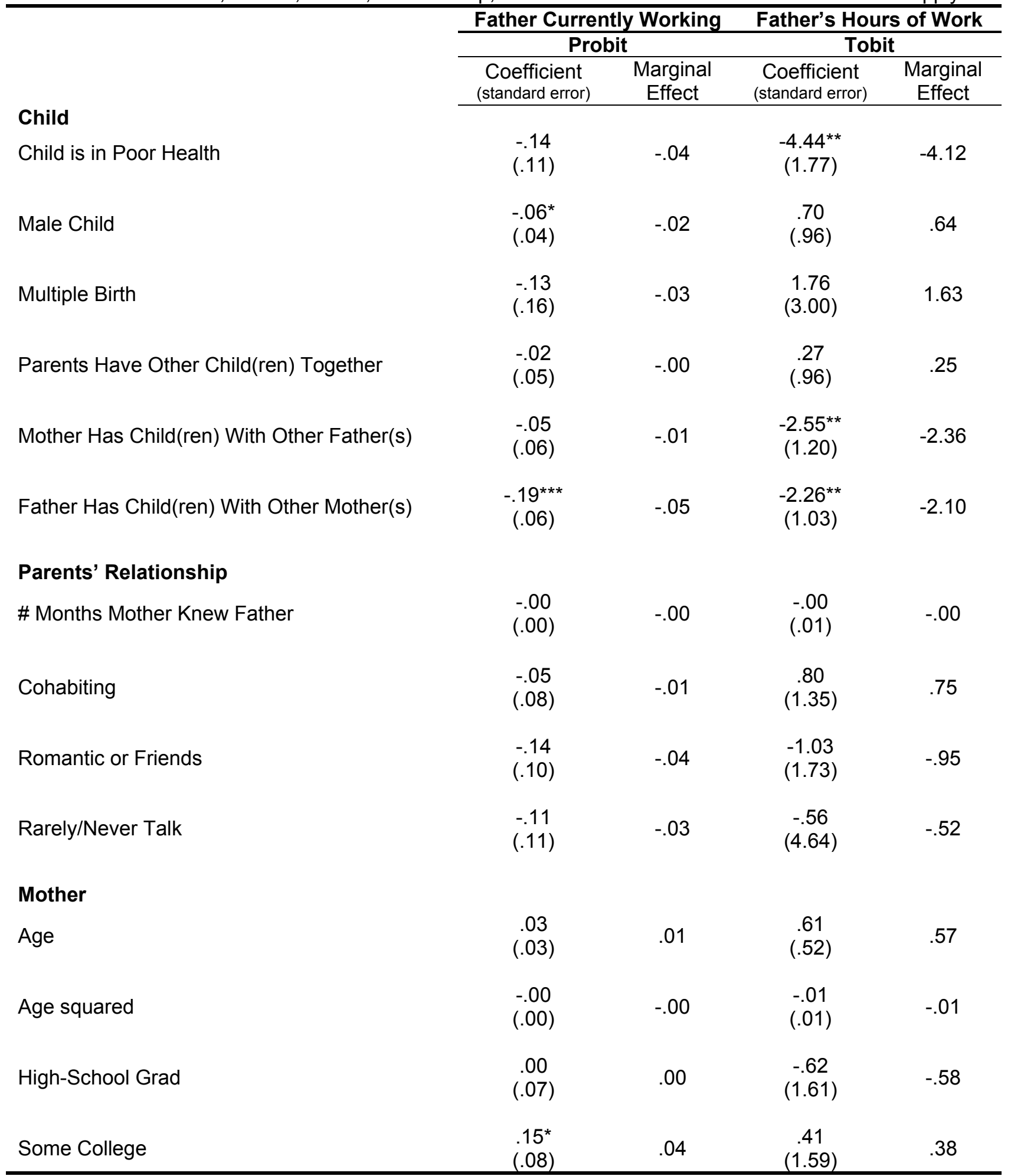


Table 3 (cont'd): Effects of Child, Mother, Father, Relationship, and Area Characteristics on Father's Labor Supply

\begin{tabular}{cccc}
\multicolumn{2}{c}{ Father Currently Working } & Father's Hours of Work \\
\hline \multicolumn{2}{c}{ Probit } & \multicolumn{2}{c}{ Tobit } \\
\hline Coefficient & Marginal & Coefficient & Marginal \\
(standard error) & Effect & (standard error) & Effect
\end{tabular}

\section{Mother (continued)}

College Grad

Medicaid

Hispanic

Non-White/ Non-Hispanic

Immigrant

Lived with Both Parents at Age 15

Worked Within 2 Years Before Birth

Attends Religious Services Several

Times/Month

Father

Age

Age squared

High-School Grad

Some College

College Grad

Attended Vocational School

Has Served in the Military

Ever Convicted of a Crime $.25^{\star *}$

(.12)

$-.19^{* * *}$

(.05)

$-.13$

(.09)

$-.38^{* * *}$

(.12)

.20

(.14)

$-.02$

(.05)

.00

(.07)

.01

(.04)

$.08^{* * *}$

(.02)

$-.00^{* * *}$

(.00)

$.21^{\text {** }}$

(.05)

$.32^{\star \star \star}$

(.07)

$.26^{* *}$

(.12)

.01

(.09)

.00

(.11)

$-.22^{\star \star \star}$

(.07)
.06

$-.05$

$-.03$

$-.10$

.05

$-.00$

.00

.71

(1.62)

.66

$-3.44^{\star * *}$

(.83)

84

.90
$(2.20)$

$-3.47^{*}$

(2.05)

$-3.22$

2.59

(2.87)

2.40

.87

(1.04)

.81

$-.88$

(.98)

$-.82$

1.01

(.88)

.94

1.32

(.44)

$-.02^{\star * *}$

(.01)

$-.02$

.05

$4.56^{\star \star *}$

(1.43)

4.23

$5.99^{\star * *}$

(1.90)

5.56

$6.63^{* * *}$

(1.27)

6.15

$2.23^{\text {** }}$

(.96)

2.07

1.52

(1.58)

1.41

$-7.55^{\star \star *}$

(1.78)

$-7.00$ 
Table 3 (cont'd): Effects of Child, Mother, Father, Relationship, and Area Characteristics on Father's Labor Supply

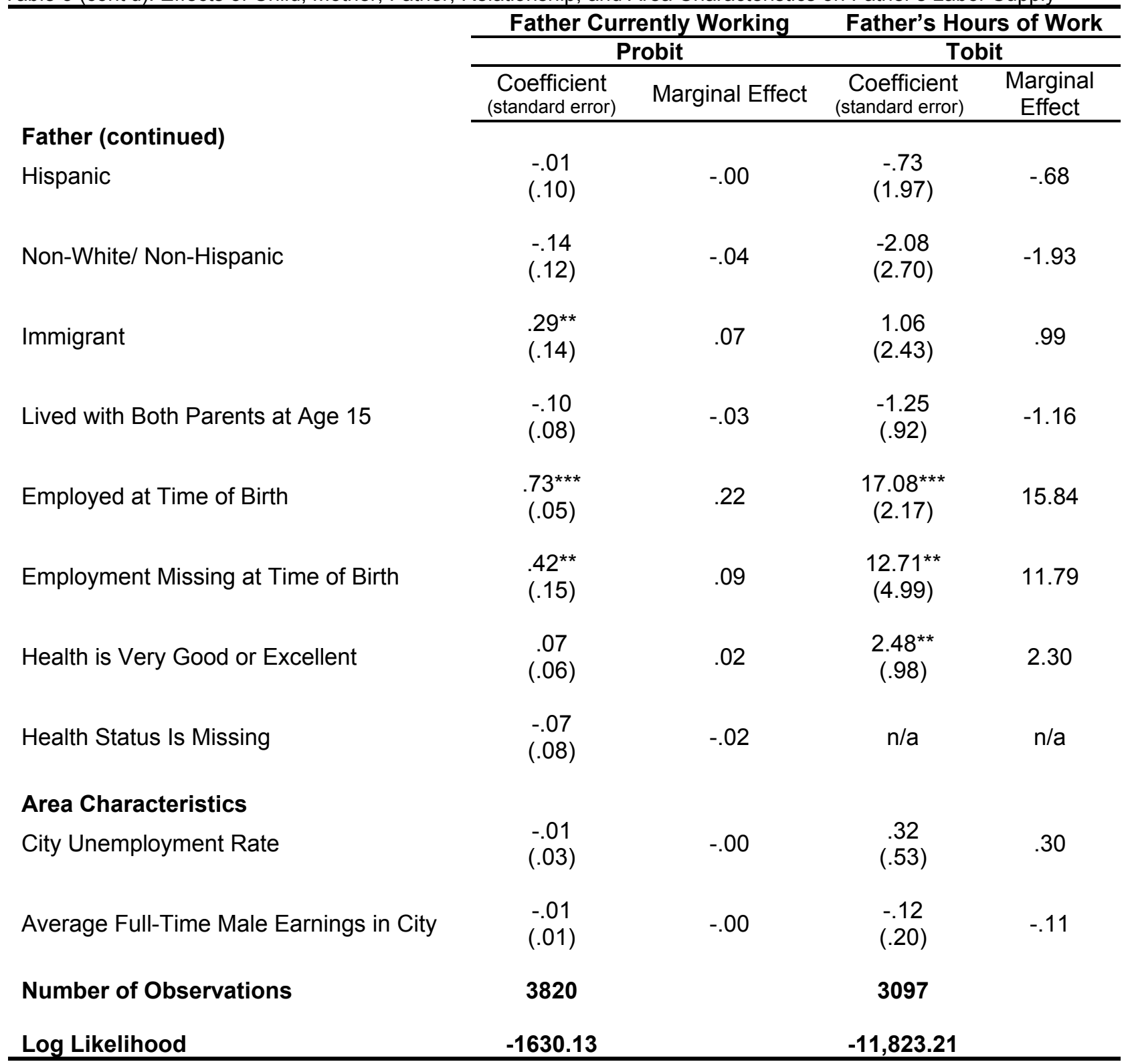

* Significant at $10 \%$ level; ${ }^{* *}$ Significant at $5 \%$ level; ${ }^{* * *}$ Significant at $1 \%$ level Notes: (City) clustered robust standard errors in parentheses; all models include state fixed effects (results not presented). 
Appendix A: Table 1(a). Bivariate Probit Results of Effect of Poor Child Health on Labor Force Participation

Mother is Currently

\section{Child}

Child is in Poor Health

Male Child

Multiple Birth

Parents Have Other Child(ren) Together

Mother Has Child(ren) With Other Father(s)

Father Has Child(ren) with Other Mother(s)

\section{Parent's Relationship}

\# Months Mother Knew Father

Cohabiting

Romantic or Friends

Rarely/Never Talk

Mother

Age

Age Squared

High-School Grad

Some College

College Grad

Medicaid Working

Coefficient

(standard error)

$-.95$

(.58)

.04

(.05)

$-.22$

(.18)

$-.09^{* *}$

(.04)

$-.04$

(.07)

.09

(.05)

Father is Currently

\section{Working}

Coefficient

(standard error)

$(.05)$

.00

(.00)

$.19^{* * *}$

(.06)

$.19^{* *}$

(.09)

.19

(.14)

.06

(1.24)

$-.07$

(.04)

$-.13$

(.16)

$-.01$

(.06)

$-.05$

(.06)

$-.19^{* * *}$

(.06)

$-.00$

(.00)

$-.05$

(.09)

$-.14$

(.11)

$-.11$

(.11)

$.12^{\star \star \star}$

(.02)

.03

(.03)

$-.00^{\star * *}$

(.00)

$-.00$

(.00)

$.30^{* * *}$

(.04)

.00

(.07)

$.60^{* \star *}$

(.07)

$.15^{*}$

(.08)

$.71^{* \star *}$

(.12)

$.25^{\text {** }}$

(.12)

$-.30^{* * *}$ (.05) 
Appendix A: Table 1(a). (cont'd) Bivariate Probit Results of Effect of Poor Child Health on Labor Force Participation

\begin{tabular}{|c|c|c|}
\hline & $\begin{array}{c}\text { Mother is Currently } \\
\text { Working }\end{array}$ & $\begin{array}{c}\text { Father is Currently } \\
\text { Working }\end{array}$ \\
\hline & $\begin{array}{c}\text { Coefficient } \\
\text { (standard error) }\end{array}$ & $\begin{array}{c}\text { Coefficient } \\
\text { (standard error) }\end{array}$ \\
\hline \multicolumn{3}{|l|}{ Mother (continued) } \\
\hline Hispanic & $\begin{array}{l}.15 \\
(.09)\end{array}$ & $\begin{array}{l}-.12 \\
(.09)\end{array}$ \\
\hline Non-White/Non-Hispanic & $\begin{array}{l}-.03 \\
(.11)\end{array}$ & $\begin{array}{c}-.38^{* * *} \\
(.12)\end{array}$ \\
\hline Immigrant & $\begin{array}{l}-.11 \\
(.09)\end{array}$ & $\begin{array}{l}.20 \\
(.14)\end{array}$ \\
\hline Lived with Both Parents at Age 15 & $\begin{array}{l}-.02 \\
(.05)\end{array}$ & $\begin{array}{l}-.02 \\
(.05)\end{array}$ \\
\hline Worked Within 2 Years Before Birth & $\begin{array}{l}1.02^{* * *} \\
(.04)\end{array}$ & $\begin{array}{l}.00 \\
(.08)\end{array}$ \\
\hline Health is Very Good or Excellent & $\begin{array}{l}-.02 \\
(.05)\end{array}$ & $\mathrm{n} / \mathrm{a}$ \\
\hline Attends Religious Services Several Times/Month & $\begin{array}{l}-.03 \\
(.04)\end{array}$ & $\begin{array}{l}.01 \\
(.04)\end{array}$ \\
\hline \multicolumn{3}{|l|}{ Father } \\
\hline Age & $\begin{array}{l}-.03^{*} \\
(.02)\end{array}$ & $\begin{array}{l}.08^{\star * *} \\
(.02)\end{array}$ \\
\hline Age Squared & $\begin{array}{l}.00 \\
(.00)\end{array}$ & $\begin{array}{c}-.00^{* * *} \\
(.00)\end{array}$ \\
\hline High-School Grad & $\begin{array}{l}-.02 \\
(.03)\end{array}$ & $\begin{array}{l}.21^{* * *} \\
(.05)\end{array}$ \\
\hline Some College & $\begin{array}{l}.03 \\
(.04)\end{array}$ & $\begin{array}{l}.33^{* * *} \\
(.10)\end{array}$ \\
\hline College Grad & $\begin{array}{l}-.15 \\
(.11)\end{array}$ & $\begin{array}{l}.27^{* *} \\
(.14)\end{array}$ \\
\hline Attended Vocational School & $\mathrm{n} / \mathrm{a}$ & $\begin{array}{c}.01 \\
(.08)\end{array}$ \\
\hline Has Served in the Military & $\mathrm{n} / \mathrm{a}$ & $\begin{array}{l}.00 \\
(.11)\end{array}$ \\
\hline Ever Convicted of a Crime & $\mathrm{n} / \mathrm{a}$ & $\begin{array}{c}-.21^{* \star *} \\
(.07)\end{array}$ \\
\hline Hispanic & $\begin{array}{l}.00 \\
(.08) \\
\end{array}$ & $\begin{array}{l}-.01 \\
(.10) \\
\end{array}$ \\
\hline
\end{tabular}


Appendix A: Table 1(a). (cont'd) Bivariate Probit Results of Effect of Poor Child Health on Labor Force Participation

\begin{tabular}{|c|c|c|}
\hline & $\begin{array}{c}\text { Mother is Currently } \\
\text { Working }\end{array}$ & $\begin{array}{c}\text { Father is Currently } \\
\text { Working }\end{array}$ \\
\hline & $\begin{array}{c}\text { Coefficient } \\
\text { (standard error) }\end{array}$ & $\begin{array}{c}\text { Coefficient } \\
\text { (standard error) }\end{array}$ \\
\hline \multicolumn{3}{|l|}{ Father (continued) } \\
\hline Non-White/Non-Hispanic & $\begin{array}{l}.20^{* *} \\
(.09)\end{array}$ & $\begin{array}{l}-.14 \\
(.12)\end{array}$ \\
\hline Immigrant & $\mathrm{n} / \mathrm{a}$ & $\begin{array}{l}.29^{* *} \\
(.14)\end{array}$ \\
\hline Lived with Both Parents at Age 15 & $\mathrm{n} / \mathrm{a}$ & $\begin{array}{l}-.10 \\
(.08)\end{array}$ \\
\hline Employed at Time of Birth & $\mathrm{n} / \mathrm{a}$ & $\begin{array}{l}.73^{\star * *} \\
(.06)\end{array}$ \\
\hline Employment Missing at Time of Birth & $\mathrm{n} / \mathrm{a}$ & $\begin{array}{l}.42^{* *} \\
(.15)\end{array}$ \\
\hline Health is Very Good or Excellent & $\begin{array}{l}-.01 \\
(.07)\end{array}$ & $\begin{array}{l}.07 \\
(.06)\end{array}$ \\
\hline Health Status is Missing & $\begin{array}{l}.10 \\
(.09)\end{array}$ & $\begin{array}{l}-.07 \\
(.08)\end{array}$ \\
\hline \multicolumn{3}{|l|}{ Area Characteristics } \\
\hline City Unemployment Rate & $\begin{array}{l}.09^{* * *} \\
(.03)\end{array}$ & $\begin{array}{l}-.01 \\
(.03)\end{array}$ \\
\hline Average Full-Time Female Earnings in City & $\begin{array}{l}.08^{* * *} \\
(.02)\end{array}$ & $\mathrm{n} / \mathrm{a}$ \\
\hline Average Full-Time Male Earnings in City & $\mathrm{n} / \mathrm{a}$ & $\begin{array}{l}-.01 \\
(.01)\end{array}$ \\
\hline $\begin{array}{l}\text { \# Adoption Agencies per } 10,000 \text { Women in City } \\
\text { Aged } 15-44\end{array}$ & $\mathrm{n} / \mathrm{a}$ & $\mathrm{n} / \mathrm{a}$ \\
\hline Level III NICU in Birth Hospital & $\mathrm{n} / \mathrm{a}$ & $\mathrm{n} / \mathrm{a}$ \\
\hline Log Likelihood & -3208.95 & -2441.21 \\
\hline Rho & $\begin{array}{l}.34 \\
(.29)\end{array}$ & $\begin{array}{l}-.10 \\
(.58)\end{array}$ \\
\hline Number of Observations & 3998 & 3820 \\
\hline
\end{tabular}

${ }^{*}$ Significant at $10 \%$ level; ** Significant at $5 \%$ level; ${ }^{* * *}$ Significant at $1 \%$ level Notes: (City) clustered robust standard errors in parentheses; all models include state fixed effects (results not presented). 
Appendix A: Table 1(b). Bivariate Probit Estimates of Poor Child Health

\begin{tabular}{|c|c|c|}
\hline \multirow[b]{4}{*}{ Child } & Mother & Father \\
\hline & Child is In Poor Health & Child is In Poor Health \\
\hline & $\begin{array}{c}\text { Coefficient } \\
\text { (standard error) }\end{array}$ & $\begin{array}{c}\text { Coefficient } \\
\text { (standard error) }\end{array}$ \\
\hline & & \\
\hline Male Child & $\begin{array}{l}.16^{\star * *} \\
(.05)\end{array}$ & $\begin{array}{l}.14^{* *} \\
(.05)\end{array}$ \\
\hline Multiple Birth & $\mathrm{n} / \mathrm{a}$ & $\mathrm{n} / \mathrm{a}$ \\
\hline Parents Have Other Child(ren) Together & $\begin{array}{c}-.15^{\star *} \\
(.07)\end{array}$ & $\begin{array}{c}-.18^{* *} \\
(.07)\end{array}$ \\
\hline Mother Has Child(ren) With Other Father(s) & $\begin{array}{c}.02 \\
(.06)\end{array}$ & $\begin{array}{c}.05 \\
(.08)\end{array}$ \\
\hline Father Has Child(ren) with Other Mother(s) & $\mathrm{n} / \mathrm{a}$ & $\mathrm{n} / \mathrm{a}$ \\
\hline \multicolumn{3}{|l|}{ Parents' Relationship } \\
\hline \# Months Mother Knew Father & $\begin{array}{l}-.00 \\
(.00)\end{array}$ & $\begin{array}{c}.00 \\
(.00)\end{array}$ \\
\hline Cohabiting & $\begin{array}{c}.07 \\
(.09)\end{array}$ & $\begin{array}{c}.04 \\
(.10)\end{array}$ \\
\hline Romantic or Friends & $\begin{array}{c}.20 \\
(.13)\end{array}$ & $\begin{array}{c}.14 \\
(.16)\end{array}$ \\
\hline Rarely/Never Talk & $\begin{array}{l}-.13 \\
(.20)\end{array}$ & $\begin{array}{l}-.24 \\
(.23)\end{array}$ \\
\hline \multicolumn{3}{|l|}{ Mother } \\
\hline Age & $\begin{array}{c}.00 \\
(.05)\end{array}$ & $\begin{array}{c}.01 \\
(.05)\end{array}$ \\
\hline Age Squared & $\begin{array}{c}.00 \\
(.00)\end{array}$ & $\begin{array}{l}-.00 \\
(.00)\end{array}$ \\
\hline High-School Grad & $\begin{array}{l}-.01 \\
(.10)\end{array}$ & $\begin{array}{l}-.01 \\
(.09)\end{array}$ \\
\hline Some College & $\begin{array}{l}-.02 \\
(.06)\end{array}$ & $\begin{array}{l}-.01 \\
(.08)\end{array}$ \\
\hline College Grad & $\begin{array}{l}-.01 \\
(.10)\end{array}$ & $\begin{array}{l}-.00 \\
(.10)\end{array}$ \\
\hline Medicaid & $\begin{array}{c}.07 \\
(.07)\end{array}$ & $\begin{array}{c}.04 \\
(.07)\end{array}$ \\
\hline Hispanic & $\begin{array}{l}-.21^{*} \\
(.12)\end{array}$ & $\begin{array}{c}-.21^{* *} \\
(.10)\end{array}$ \\
\hline Non-White/Non-Hispanic & $\begin{array}{l}-.08 \\
(.08)\end{array}$ & $\begin{array}{l}-.08 \\
(.08)\end{array}$ \\
\hline
\end{tabular}


Appendix A: Table 1(b). (cont'd) Bivariate Probit Estimates of Poor Child Health

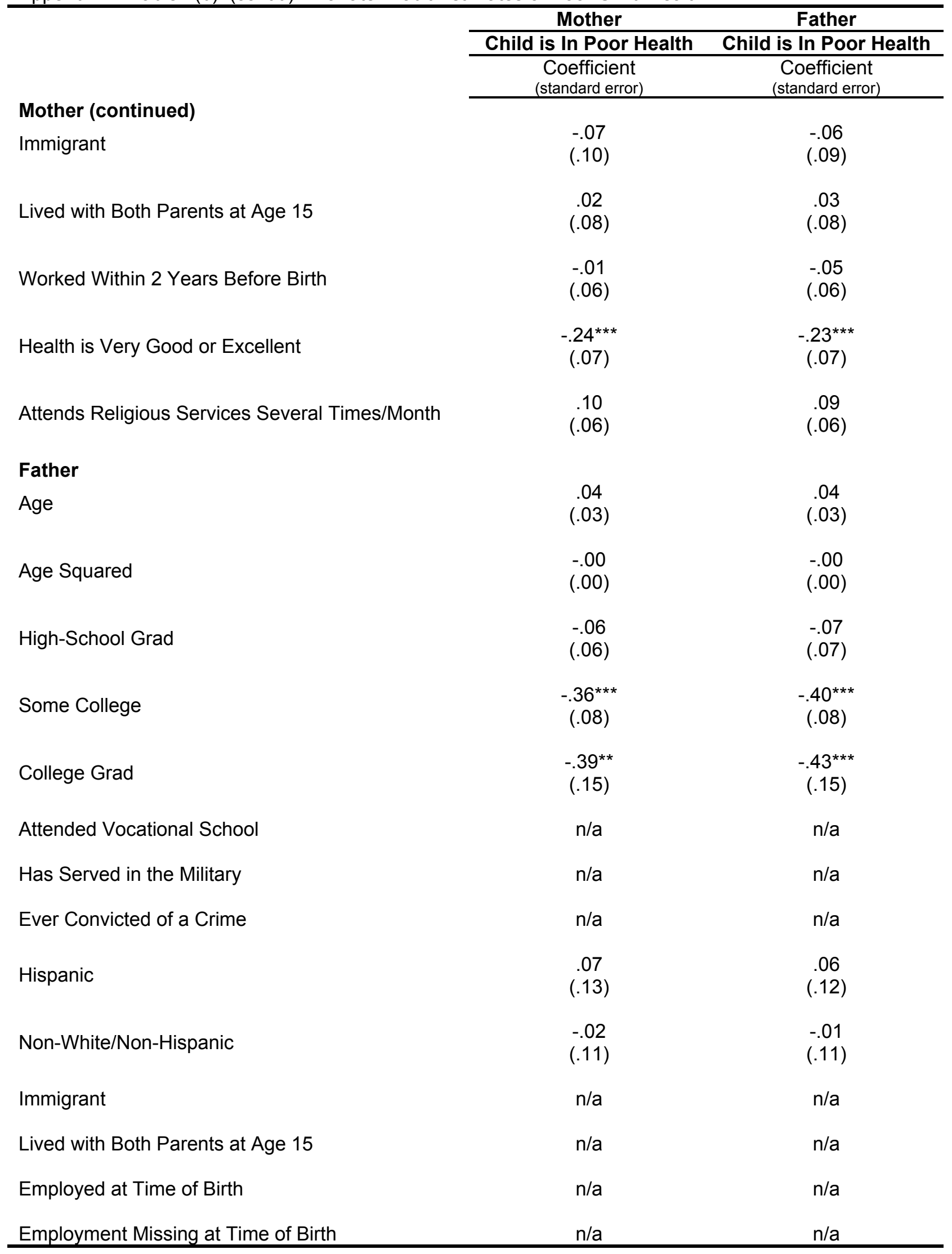


Appendix A: Table 1(b). (cont'd) Bivariate Probit Results of Poor Child Health

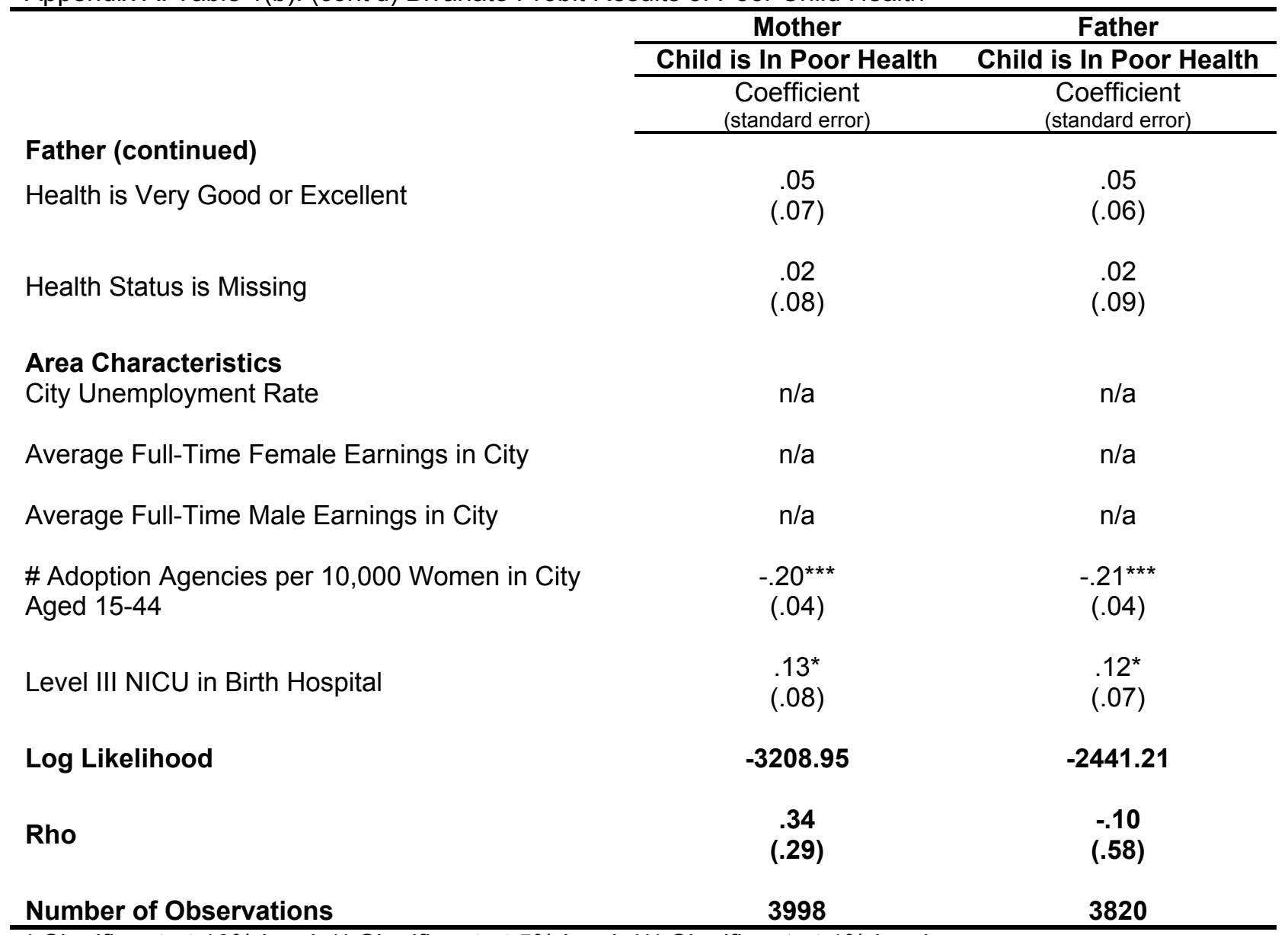

* Significant at $10 \%$ level; ** Significant at $5 \%$ level; ${ }^{* *}$ Significant at $1 \%$ level

Notes: (City) clustered robust standard errors in parentheses; all models include state fixed effects (results not presented). 
Appendix B: Table 1. Effects of Child, Mother, Father, Relationship, and Area Characteristics on Labor Supply of Unmarried Mothers

\begin{tabular}{|c|c|}
\hline Mother Currently Working & Mother's Hours of Work \\
\hline Probit & Tobit \\
\hline $\begin{array}{l}\text { Coefficient } \\
\text { (standard } \\
\text { error) }\end{array}$ & $\begin{array}{c}\text { Coefficient } \\
\text { (standard error) }\end{array}$ \\
\hline
\end{tabular}

\section{Child}

Child is in Poor Health

$-.32^{* * *}$

$(.08)$

$-.13$

$-9.08^{* * *}$

.05

Male Child

(.06)

.02

$(2.14)$

$-5.55$

Multiple Birth

(.18)

$-.00$

1.03

$(1.44)$

.63

Parents Have Other Child(ren) Together

$-.14^{* *}$

(.06)

$-.05$

$-.11$

$(4.66)$

$-.07$

Mother Has Child(ren) With Other Father(s)

$-.08$

(.07)

$-.03$

$-2.71^{* *}$

$-1.66$

Father Has Child(ren) with Other Mother(s)

.03

$-1.11$

(1.75)

$-.68$

Parents' Relationship

\# Months Mother Knew Father

.00

$(.00)$

.00

(.02)

.00

Romantic or Friends

$-.01$

(.06)

$-.01$

$-1.49$

(1.42)

$-.91$

Rarely/Never Talk

.00
$(.12)$

.00

$-.27$

(2.93)

$-.16$

\section{Mother}

Age

$.16^{\star * *}$

.06

$4.15^{\star \star \star}$

(.80)

2.53

Age squared

$-.00^{* * *}$

(.00)

$-.00$

$-.01^{* * *}$

(.01)

$-.04$

High-School Grad

$.32^{* * *}$

(.04)

.13

$10.01^{\text {*** }}$

(1.28)

6.12

Some College

$.59^{* * *}$

(.06)

.23

$15.49^{* * *}$

(1.62)

9.47

College Grad

$.51^{* *}$

(.20)

$15.66^{* * *}$ 
Appendix B: Table 1. (cont'd) Effects of Child, Mother, Father, Relationship, and Area Characteristics on Labor Supply of Unmarried Mothers

\section{Mother (continued)}

Medicaid

Hispanic

$(.12)$

\begin{tabular}{|c|c|}
\hline Mother Currently Working & Mother's Hours of Work \\
\hline Probit & Tobit \\
\hline $\begin{array}{l}\text { Coefficient } \\
\text { (standard error) }\end{array}$ & $\begin{array}{c}\text { Coefficient } \\
\text { (standard error) }\end{array}$ Marginal Effect \\
\hline
\end{tabular}

Non-White/ Non-Hispanic

$-.06$

(.14)

$-.41^{* * *}$

$(.07)$

$-.16$

$-9.13^{* * *}$

(1.65)

$-5.58$

16

$-.08$

Immigrant

(.10)

.06

4.09

(3.00)

2.50

$-.06$

(.05)

$-.02$

1.38

(3.56)

$-.84$

Lived with Both Parents at Age 15

$.89^{* * *}$

Worked Within 2 Years Before Birth

(.06)

.34

$-1.85$

(2.89)

$-1.13$

$-1.44$

(1.14)

$-.88$

Health is Very Good or Excellent

.01

(.05)

.00

$26.48^{\text {*** }}$

(2.10)

16.19

$-.03$

Attends Religious Services Several

(.05)

$-.01$

$-.24$

(1.44)

$-.14$

Times/Month

$-1.29$

(1.21)

$-.79$

Father

Age

$-.04^{* *}$

(.02)

$-.01$

$-1.01^{* *}$

(.49)

$-.62$

Age squared

$.00^{*}$

(.00)

.00

$.01 *$

(.01)

.01

High-School Grad

$-.01$

(.04)

$-.00$

$-.26$

(.98)

$-.16$

Some College

.05

(.05)

.02

1.45

(1.25)

.89

College Grad

.22

(.14)

.09

2.38

(2.81)

1.46

Hispanic

.02

(.09)

.01

1.69

(2.37)

1.03

Non-White/ Non-Hispanic

$.22^{* *}$

(.11)

.09

$7.46^{* *}$

(3.02)

4.56 
Appendix B: Table 1. (cont'd) Effects of Child, Mother, Father, Relationship, and Area Characteristics on Labor Supply of Unmarried Mothers

\section{Father (continued) \\ Health is Very Good or Excellent}

Health Status Missing

Area Characteristics

City Unemployment Rate

Average Full-Time Female Earnings in City

Number of Observations

Log Likelihood

\begin{tabular}{cccc}
\multicolumn{2}{c}{ Mother Currently Working } & \multicolumn{2}{c}{ Mother's Hours of Work } \\
\hline \multicolumn{2}{c}{ Probit } & \multicolumn{2}{c}{ Tobit } \\
\hline $\begin{array}{c}\text { Coefficient } \\
\text { (standard error) }\end{array}$ & Marginal Effect & $\begin{array}{c}\text { Coefficient } \\
\text { (standard error) }\end{array}$ & Marginal Effect \\
\hline & & & \\
-.01 & -.00 & $(1.96)$ & -.14 \\
$(.08)$ & & 3.38 & \\
& & $(2.06)$ & 2.06 \\
.14 & .06 & & \\
$(.09)$ & & $2.39^{* *}$ & 1.46 \\
& & $(.89)$ & \\
$.09^{* * *}$ & .03 & $2.09^{* * *}$ & 1.28 \\
$(.03)$ & & $(.53)$ & \\
$.07^{* * *}$ & .03 & $\mathbf{2 9 3 3}$ & \\
$(.02)$ & & $\mathbf{8 , 5 5 7 . 9 7}$ & \\
$\mathbf{2 9 6 5}$ & &
\end{tabular}

* Significant at $10 \%$ level; ** Significant at $5 \%$ level; ${ }^{* *}$ Significant at $1 \%$ level Notes: (City) clustered robust standard errors in parentheses; all models include state fixed effects (results not presented). 
Appendix B: Table 2. Effects of Child, Mother, Father, Relationship, and Area Characteristics on Labor Supply of Unmarried Fathers

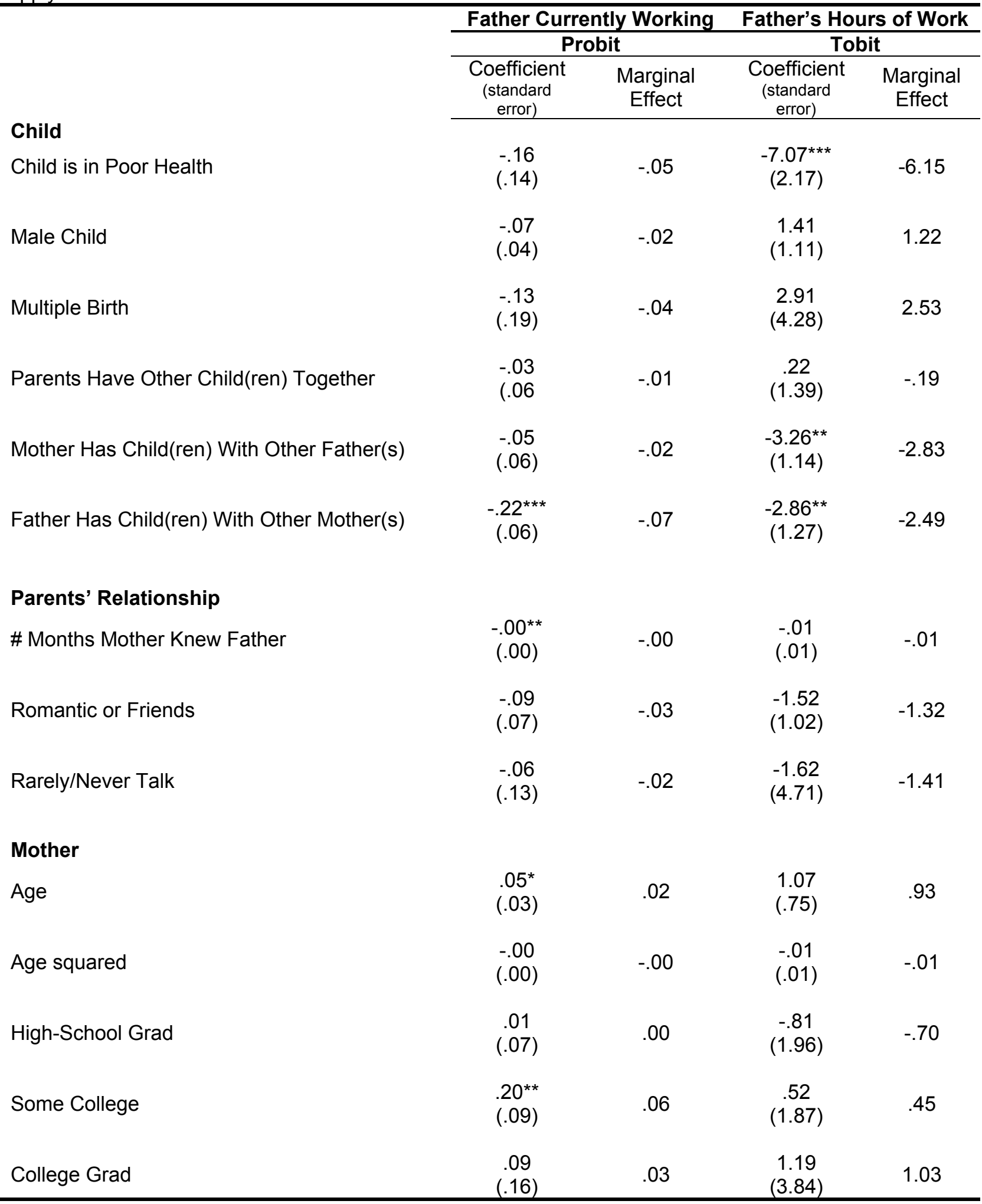


Appendix B: Table 2. (cont'd) Effects of Child, Mother, Father, Relationship, and Area Characteristics on Labor Supply of Unmarried Fathers

\section{Mother (continued)}

Medicaid

Hispanic

Non-White/ Non-Hispanic

Immigrant

Lived with Both Parents at Age 15

Worked Within 2 Years Before Birth

Attends Religious Services Several

Times/Month

\section{Father}

Age

Age squared

High-School Grad

Some College

College Grad

Attended Vocational School

Has Served in the Military

Ever Convicted of a Crime

Hispanic

\begin{tabular}{cccc}
\multicolumn{2}{c}{ Father Currently Working } & \multicolumn{2}{c}{ Father's Hours of Work } \\
\hline \multicolumn{2}{c}{ Probit } & \multicolumn{2}{c}{ Tobit } \\
\hline Coefficient & Marginal & Coefficient & Marginal \\
(standard error) & Effect & (standard error) & Effect
\end{tabular}

$-.16^{* * *}$

(.05)

$-.16$

(.13)

$-.49^{* * *}$

(.14)

$.34^{* *}$

(.14)

$-.05$

(.04)

$-.01$

(.09)

$-.02$

(.04)

$.06^{* \star}$

(.02)

$-.00^{* *}$

$(.00)$

$.24^{* * *}$

(.05)

$.36^{* * *}$

(.08)

$.48^{* *}$

(.18)

$-.01$

(.09)

$-.03$

(.12)

$-.24^{* * *}$

(.07)

.05

(.10)
$-.05$

$-.05$

$-.15$

.09

$-.02$

$-.00$

$-.01$

$-3.96^{* * *}$

(1.29)

1.10

(2.55)

$-5.63^{*}$

(2.98)

$-4.89$

.13

(3.34)

.11

.38

(1.30)

$-1.36$

(1.12)

$-1.18$

.95

1.09
$(1.05)$

$1.22^{* *}$

(.55)

1.06

$-.02^{* *}$

(.01)

$-.02$

$5.86^{\star * *}$

(1.76)

5.10

$7.65^{\star \star \star}$

(2.15)

6.65

$11.09^{* * *}$

(2.54)

9.64

$\begin{array}{rr}-.00 & 2.87^{\star *} \\ & (1.32)\end{array}$

$\begin{array}{ll}-.00 & 2.87^{\star \star} \\ & (1.32)\end{array}$

2.49

.35

(1.97)

.31

$-8.85^{* * *}$

(2.18)

$-7.70$

$-2.11$

(2.67)

$-1.84$ 
Appendix B: Table 2. (cont'd) Effects of Child, Mother, Father, Relationship, and Area Characteristics on Labor Supply of Unmarried Fathers

\begin{tabular}{|c|c|c|c|c|}
\hline \multirow[b]{3}{*}{ Father (continued) } & \multicolumn{2}{|c|}{$\begin{array}{c}\text { Father Currently Working } \\
\text { Probit } \\
\end{array}$} & \multicolumn{2}{|c|}{$\begin{array}{c}\text { Father's Hours of Work } \\
\text { Tobit } \\
\end{array}$} \\
\hline & $\begin{array}{l}\text { Coefficient } \\
\text { (standard error) }\end{array}$ & Marginal Effect & $\begin{array}{r}\text { Coefficient } \\
\text { (standard error) }\end{array}$ & $\begin{array}{l}\text { Marginal } \\
\text { Effect }\end{array}$ \\
\hline & & & & \\
\hline Non-White/ Non-Hispanic & $\begin{array}{l}-.02 \\
(.12)\end{array}$ & -.01 & $\begin{array}{l}-3.46 \\
(3.78)\end{array}$ & -3.01 \\
\hline Immigrant & $\begin{array}{l}.28^{* *} \\
(.14)\end{array}$ & .08 & $\begin{array}{l}3.55 \\
(2.64)\end{array}$ & 3.09 \\
\hline Lived with Both Parents at Age 15 & $\begin{array}{c}-.14^{* *} \\
(.06)\end{array}$ & -.04 & $\begin{array}{l}-1.73 \\
(1.05)\end{array}$ & -1.50 \\
\hline Employed at Time of Birth & $\begin{array}{l}.69^{* * *} \\
(.06)\end{array}$ & .23 & $\begin{array}{c}17.34^{* * *} \\
(2.48)\end{array}$ & 15.07 \\
\hline Employment Missing at Time of Birth & $\begin{array}{l}.43^{* *} \\
(.17)\end{array}$ & .11 & $\begin{array}{c}13.31^{* *} \\
(5.51)\end{array}$ & 11.57 \\
\hline Health is Very Good or Excellent & $\begin{array}{c}.03 \\
(.07)\end{array}$ & .01 & $\begin{array}{l}2.60^{* *} \\
(1.25)\end{array}$ & 2.26 \\
\hline Health Status Is Missing & $\begin{array}{l}-.15 \\
(.10)\end{array}$ & -.05 & $\mathrm{n} / \mathrm{a}$ & $\mathrm{n} / \mathrm{a}$ \\
\hline \multicolumn{5}{|l|}{ Area Characteristics } \\
\hline City Unemployment Rate & $\begin{array}{c}.01 \\
(.03)\end{array}$ & .00 & $\begin{array}{l}.54 \\
(.68)\end{array}$ & .47 \\
\hline Average Full-Time Male Earnings in City & $\begin{array}{l}-.00 \\
(.00)\end{array}$ & -.00 & $\begin{array}{l}-.18 \\
(.26)\end{array}$ & -.16 \\
\hline Number of Observations & 2806 & & 2185 & \\
\hline Log Likelihood & -1388.99 & & $-8,060.52$ & \\
\hline
\end{tabular}

* Significant at $10 \%$ level; ${ }^{* *}$ Significant at $5 \%$ level; *** Significant at $1 \%$ level Notes: (City) clustered robust standard errors in parentheses; all models include state fixed effects (results not presented). 